\title{
A Flowable Placental Tissue Matrix Allograft in Lower Extremity Injuries: A Pilot Study
}

Eric Lullove ${ }^{1}$

1. West Boca Medical Center, Boca Raton, FL

$\square$ Corresponding author: Eric Lullove, loo0903@gmail.com

Disclosures can be found in Additional Information at the end of the article

\section{Abstract}

Damaged connective tissue commonly leads to lower extremity injuries. These injuries can result in inflammation, reduced mobility, and chronic pain. Conservative treatment may include orthotics, offloading the injury, physical therapy, and/or NSAIDs. If conservative treatment fails, surgical intervention may be required. Even after successful surgery, these procedures often result in reduced joint mobility and tendon or ligament strength.

A novel flowable tissue matrix allograft, derived from human placental connective tissue, has recently been made available for minimally invasive treatment of damaged or inadequate tissue (PX50® ${ }^{\circledR}$, Human Regenerative Technologies LLC, Redondo Beach, CA).

Based on the universal role of connective tissue in the body, and its reported antimicrobial, anti-adhesive, and anti-inflammatory properties, we assessed the effects of using this placental tissue matrix in the treatment of a series of lower extremity injuries.

In this pilot study, 9 of 10 patients reported pain levels of 2 or less by week four using the VAS pain scale. This short-term pilot study effectively shows that injectable, flowable amniotic allografts can be used for orthopedic sports injuries of the lower extremities.

Categories: Orthopedics

Keywords: sports injuries, amniotic allograft, injectables, allografts, human placenta, sports medicine

\section{Introduction}

Received 04/20/2015

Review began 05/04/2015

Review ended 06/07/2015

Published 06/10/2015

C Copyright 2015

Lullove. This is an open access article distributed under the terms of the Creative Commons Attribution License CC-BY 3.0., which permits unrestricted use, distribution, and reproduction in any medium, provided the original author and source are credited.
Damaged connective tissue commonly leads to lower extremity injuries. These injuries can result in inflammation, reduced mobility, and chronic pain [1]. Conservative treatment may include orthotics, offloading the injury, physical therapy, NSAIDs. If conservative treatment fails, surgical intervention may be required. Even after successful surgery, these procedures often result in reduced joint mobility and tendon or ligament strength [2-3].

A novel flowable tissue matrix allograft, derived from human placental connective tissue, has recently been made available for minimally invasive treatment of damaged or inadequate tissue (PX50 ${ }^{\circledR}$, Human Regenerative Technologies LLC, Redondo Beach, CA).

Based on the universal role of connective tissue in the body [4], and its reported antimicrobial, anti-adhesive, anti-inflammatory properties, we assessed the effects of using this placental tissue matrix in the treatment of a series of lower extremity injuries. 


\section{Characteristics of connective tissue}

Connective tissue is one of the four fundamental types of biological tissue found in the human body [4]. It is the most abundant, widely distributed tissue [4], making up a large proportion of the total body mass [5].

Connective tissue is found under the skin and all epithelia; in the outer covering of nerves; around organs; in the fascia between muscles; in the fibrous sheath around bones; and creates tendons, ligaments, cartilage and bones [4].

All connective tissue consists of three main components: Fibers, Ground Substance and Cells. The cells of connective tissue are embedded in an ExtraCellular Matrix (ECM). The ECM, in turn, consists of the fibers embedded in a featureless 'ground substance' [5].

The function of connective tissue in the body includes the binding of organs, structural support, physical protection, immune protection, and movement [4].

\section{The placenta as a source of connective tissue}

The human placenta is a potentially rich source of biological tissue, comprising the placenta, the amniotic membranes, the amniotic fluid, the umbilical cord, and the umbilical cord blood $[6]$.

The extracellular matrix (ECM) components of these tissues include collagens (Types I, III, IV, $\mathrm{V}$, and VI), fibronectin, nidogen, laminin, proteoglycans, and hyaluronan, as well as growth factors [45].

Placental tissues have been reported to be non-immunogenic, providing a tissue source that elicits little or no immune response in the patient, reducing the risk of rejection, and graft failure [10-14]. Further, these tissues have been shown to be anti-microbial, regulate inflammation, prevent fibrosis, and support correct tissue reconstruction.

\section{History of clinical use}

Historically, most clinical reports on the use of placental tissues have discussed the use of amniotic membranes for an array of clinical applications since the 1920's [15-19]. These uses include general surgery [20-21], corneal surgery [22-24], plastic surgery [25], burns and wound care [26-32], sports medicine [33-34], foot and ankle procedures [35-36], spine and dura repair [37-44], nerve wrap or dural covering [39, 42, 45], and tendon repair [46].

\section{Materials And Methods}

The investigator contracted with Midlands IRB for this study. Midlands IRB ruled that this pilot retrospective study review of existing patient records was exempt from IRB review in accordance with 45CFR46.101B. The data collected was without identifiers or link to identifiers. Additionally, the investigator who would normally have access to the records as part of the patients' routine clinical care conducted the records review. Patients were consented to treatment prior to engagement of the injection protocol.

A retrospective pilot cohort study of 10 patients were selected from the treating physician's own patient population at a single clinical site. Male and female patients were randomly selected without bias to gender. Patients were identified as having a musculoskeletal injury involving the lower extremity. All patients were initially screened using the Visual Analog Pain Scale. Patients were identified with either acute or chronic tendon or muscular injuries of the 
lower extremities, including: posterior tibial tendonitis, peroneal tendonitis, anterior tibial tendonitis, extensor muscles of the foot, plantar musculature of the foot excluding the plantar fascia, and Achilles tendonitis.

Exclusion criteria included joint arthritis, plantar fasciitis, cellulitis of the lower leg, infection of the lower leg, or hypersensitivity to amniotic tissue products.

The qualifying patients were then identified as having the acute or chronic tendon injury defined through history and physical and musculoskeletal advanced ultrasound imaging by the treating physician. Visual pain scales were used on a weekly basis to assess patient's selfreported pain level starting at week 0 and followed through to week six.

Ultrasound non-vascular extremity examinations were performed at week 0 at the time of injection of the flowable allograft tissue matrix and again at week four and week six. Images were recorded in real-time and assessed in both longitudinal and transverse planes.

The investigator on every patient performed the injection technique of the allograft tissue. The technique included a mixture of $1.0 \mathrm{cc}$ Bupivicaine $0.5 \%$ plain and $0.5 \mathrm{cc}$ of the ambient temperature, flowable allograft tissue matrix. The injection was performed under a sterile field condition using ultrasound guidance to target the injection material to the area of injury.

Patients were then dispensed a pneumatic short leg ankle walking boot (Ossur) and instructed to utilize the boot for weight-bearing for two weeks post-injection. Patients were instructed how to use the walking boot properly and effectively for off-loading and stabilization postinjection.

In addition, demographic, injury history, and previous treatments (if applicable) were obtained. This included age, gender, ethnicity, smoking history, and BMI.

\section{Results}

Table 1 summarizes patient characteristics. 


\section{Cureus}

\begin{tabular}{|c|c|c|c|}
\hline Patient & Age & Gender & BMI \\
\hline 1 & 63 & $\mathrm{~F}$ & 31.12 \\
\hline 2 & 62 & F & 37.32 \\
\hline 3 & 35 & $M$ & 26.41 \\
\hline 4 & 77 & $M$ & 36.82 \\
\hline 5 & 23 & $\mathrm{~F}$ & 15.55 \\
\hline 6 & 54 & $\mathrm{~F}$ & 25.56 \\
\hline 7 & 34 & F & 17.42 \\
\hline 8 & 45 & F & 28.84 \\
\hline 9 & 61 & $\mathrm{~F}$ & 33.51 \\
\hline 10 & 51 & $M$ & 26.74 \\
\hline
\end{tabular}

\section{TABLE 1: Demographic Data}

Age ranges were from 23 to 77 with a median of 52.5. Seven patients were female and three were male. Almost all (nine) of the patients were white, non-Hispanic. BMI ranged from 15.55 to 37.32 with a median of 27.79. Posterior tibialis tendonitis was the predominant injury treated $(n=4)$, followed by Achilles tendonitis $(n=2)$, flexor hallucis tendonitis $(n=2)$, anterior tibialis tendonitis $(\mathrm{n}=1)$, and abductor digiti minimi tendonitis $(\mathrm{n}=1)$.

Table 2 summarizes the observations of VAS pain scores at each time point per patient. 


\section{Cureus}

\begin{tabular}{|llllllll|}
\hline & Week 0 & Week 1 & Week 2 & Week 3 & Week 4 & Week 5 & Diagnosis \\
\hline 1 & 7 & 1 & 0 & 0 & 0 & 0 & FHL tendonitis right \\
2 & 7 & 3 & 3 & 2 & 0 & 0 & Achilles tendonitis left \\
3 & 9 & 1 & 1 & 1 & 0 & 0 & Achilles tendonitis left \\
4 & 8 & 2 & 1 & 1 & 0 & 0 & Abductor digiti quinti left \\
5 & 8 & 2 & 2 & 1 & 1 & 0 & Post tibialis tendonitis left \\
6 & 7 & 4 & 9 & 9 & 2 & 0 & Post tibialis tendonitis right \\
7 & 8 & 2 & 2 & 0 & 0 & 0 & Post tibialis tendonitis right \\
8 & 2 & 3 & 1 & 1 & 0 & 0 & Post tibialis tendonitis right \\
9 & 8 & 2 & 1 & 1 & 0 & 0 & Ant tibialis tendonits left \\
10 & 10 & 2 & 1 & 1 & 0 & 0 & FHL tendonitis right \\
\hline
\end{tabular}

\section{TABLE 2: VAS Pain Scores by Visit}

Overall, all 10 patients improved to pain scores of 0 by the end of the evaluation period. Nine of the 10 patients declined as expected with their pain ratings. Only one patient had an increase of pain, and that was due to another area of the posterior tibialis tendon becoming pathologic outside of the injected target area. By week three, in nine of the 10 patients enrolled, all had pain levels improved $75 \%$ or greater by week three.

Eight of the 10 patients reported VAS pain score of 0 by week 4 .

Pre-injection pathology is shown in Figure 1. 


\section{Cureus}

\section{Ultrasound images in real-time with $18 \mathrm{mHz}$ linear probe.}

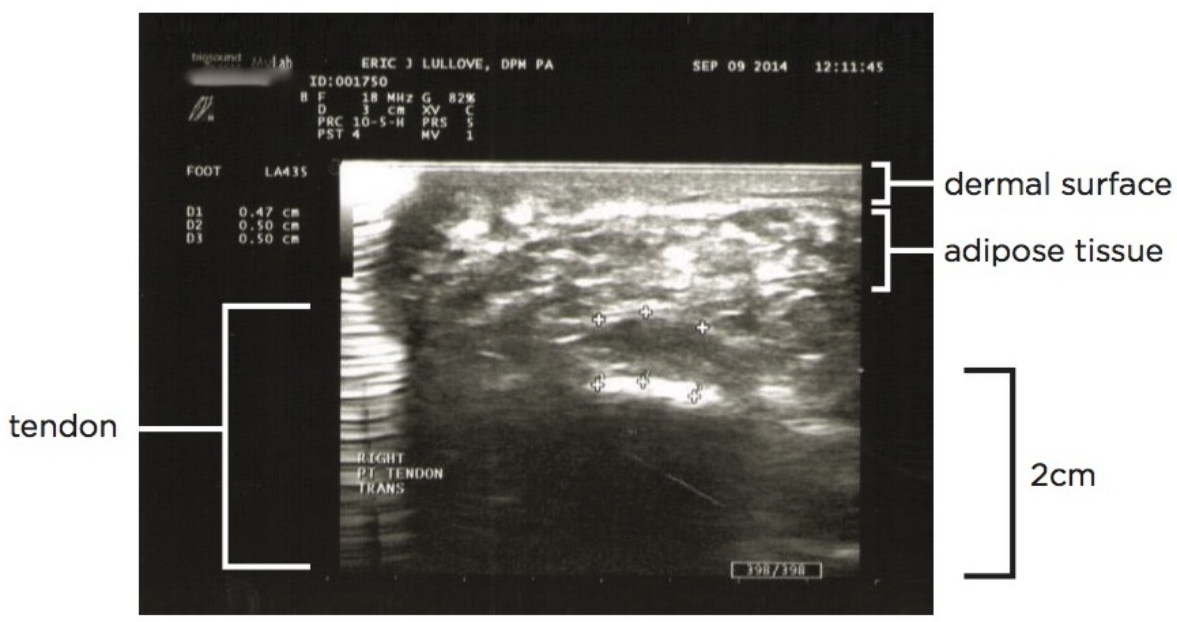

Upper photo is a transverse image showing the thickness of the posterior tibial tendon showing acute on chronic inflammation with a measurement of $0.50 \mathrm{~cm}$, which depicts tenosynovitis and tendonitis (depicted by the + from top to bottom).

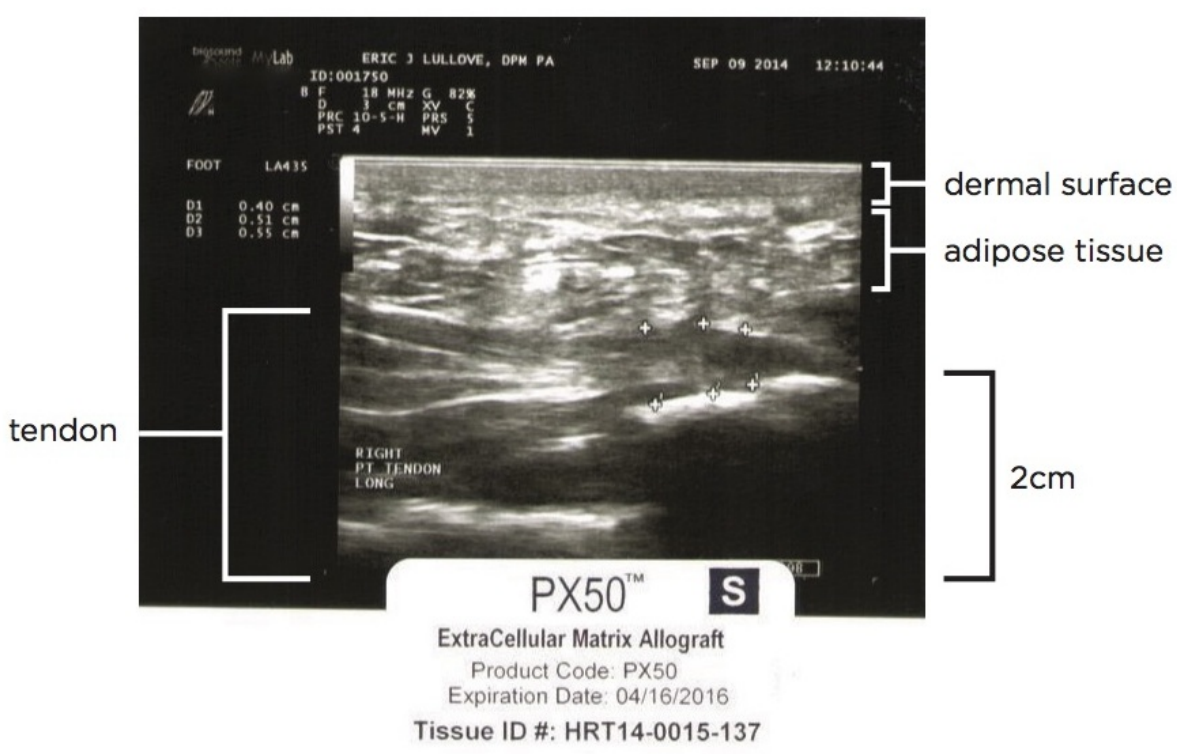

The below image is the longitudinal scan showing the same tendon with significant tenosynovitis and tendonitis with measurements of $0.55 \mathrm{~cm}$ in plane (+ from right to left).

\section{FIGURE 1: Pre-Injection Ultrasound Posterior Tibialis Tendon}

The ultrasound scan depicted shows both transverse (top) and longitudinal (bottom) planes of imaging. In the upper image, the measurement of the tendon (depicted by the hypoechoic signal between the fascial planes near the bottom) shows $0.50 \mathrm{~cm}$ in diameter, reflecting a moderately inflammed tendon. The bottom image reflects the same measurement (the hypoechoic signal between the fascial planes in the middle of the image) depicting the inflammatory tendonitis of overuse in this patient selected for injection. 


\section{Cureus}

Figure 2 shows post-injection pathology at two weeks.

\section{Ultrasound images in real-time with $18 \mathrm{mHz}$ linear probe.}

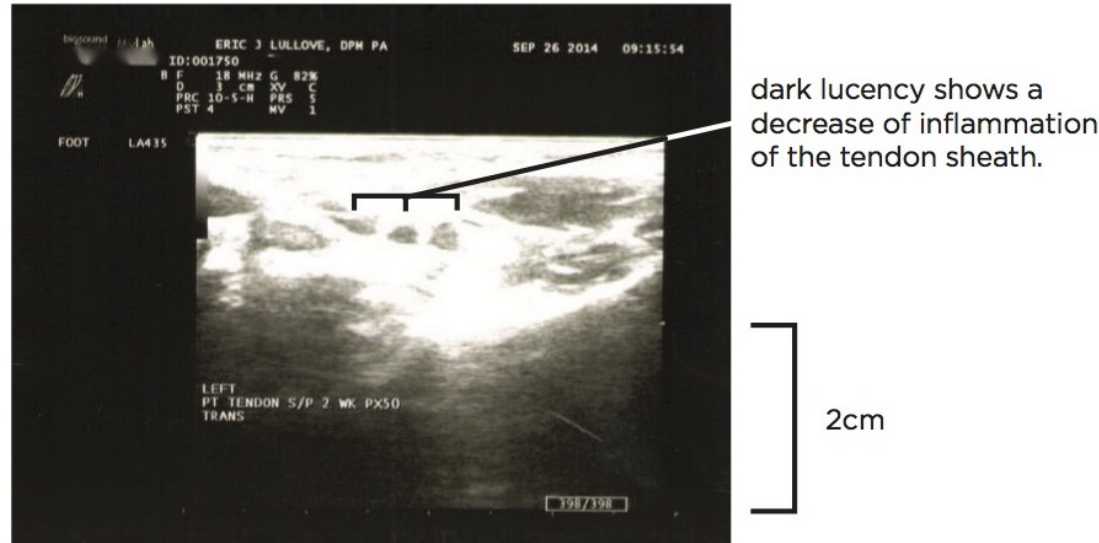

Transverse image showing the tibialis posterior tendon post-injection 2 weeks.

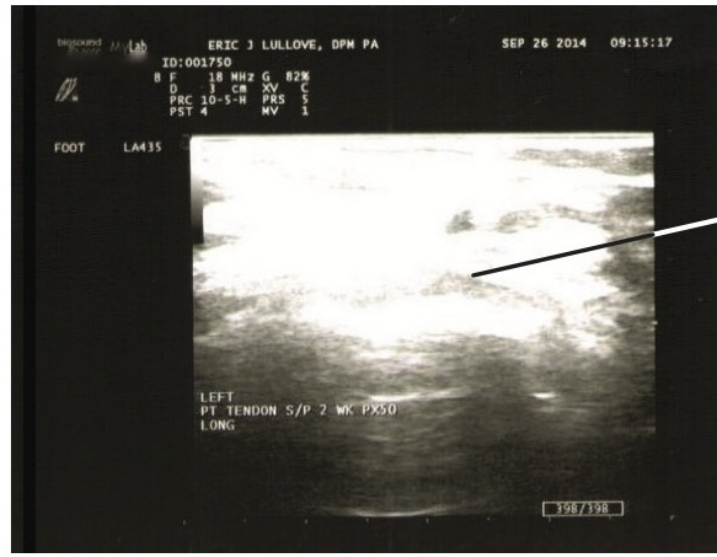

dark lucency shows a decrease of inflammation of the tendon sheath.

Longitudinal scan of the same tendon.

\section{FIGURE 2: Post-Injection Ultrasound Posterior Tibialis Tendon}

The ultrasound scan depicted shows both transverse (top) and longitudinal (bottom) planes of imaging. In the upper image, the measurement of the tendon two weeks post-injection shows a measurement of $0.21 \mathrm{~cm}$, which is a normal tendon measurement. The bottom image shows a measurement of $0.24 \mathrm{~cm}$, which also reflects a normal tendon measurement. This reflects a $90 \%$ to $95 \%$ reduction in inflammation and a good therapeutic response post-injection.

\section{Discussion}

Overall, all ten patients resolved their pain by week five. Based on the VAS pain scores reported, these 10 patients show a strong correlation for using amniotic tissue allograft injection to resolve acute tendon injuries rapidly. Further research would be needed to compare the use of amniotic allograft tissue injections versus corticosteroid injections head-to-head, and further 
larger studies, including randomized controlled trials, may elucidate the reasons for these differences.

In patients with acute tendon or musculoskeletal injuries of the lower extremities, the use of this newer injectable amniotic tissue allograft shows efficacy in reduction of pain within six weeks of injection. This particular therapy shows extensive promise in the ability to keep patients adherent to treatment regimens with a higher retention rate of success than standard tendon injury treatment techniques.

In most cases of acute on chronic tendon injury, the need for regenerative medicine modalities only increases as the population increases in age and activity level. With the advent of more active older adult lifestyles, the need for these types of therapies will be more in-demand than in years past. As technologies advance with better sports gear and equipment, so must our need as physicians to improve the outcomes of patients whose motives are for a quicker return to activities without the need for advanced surgical treatments. The need for advanced medical alternatives to surgery must be paramount in the treatment of these patient populations now and in the future.

\section{Conclusions}

Due to the nature of this single-center, single investigator study, further research is needed with a larger sample of patients to verify the VAS pain score ratings encountered here in this pilot study. While there was bias from a single investigator, the author was very careful with regard to moderating the scoring system used by the patients to report their pain. Also, the author made every attempt to reduce bias by standardizing the injection technique, the administration of local anesthetic in similar amounts to each patient, and the utilization and interpretation of ultrasound guidance.

Due to the nature of only a few injectable amniotic tissue allografts in the market, it is necessary for qualified health professionals choose the proper therapy for patients with acute tendon injuries. As with all injectable treatments, the standards of care should be used in conjunction with newer allograft techniques to obtain optimal results.

\section{Additional Information}

\section{Disclosures}

Human subjects: Consent was obtained by all participants in this study. Midlands IRB issued approval N/A. The investigator contracted with Midlands IRB for this study. Midlands IRB ruled that this pilot retrospective study review of existing patient records was exempt from IRB review in accordance with 45CFR46.101B. The data collected was without identifiers or link to identifiers. . Animal subjects: All authors have confirmed that this study did not involve animal subjects or tissue. Conflicts of interest: In compliance with the ICMJE uniform disclosure form, all authors declare the following: Payment/services info: Dr. Lullove is a paid consultant for Skye Biologics and received an unrestricted educational grant for this study. Dr. Lullove maintained independence of the research and study design and during the course of data collection. . Financial relationships: Eric J. Lullove, DPM declare(s) personal fees from Skye Biologics, Inc. Other relationships: All authors have declared that there are no other relationships or activities that could appear to have influenced the submitted work.

\section{References}

1. Kohls-Gatzoulis J, Woods B, Angel JC, Singh D: The prevalence of symptomatic posterior tibialis tendon dysfunction in women over the age of 40 in England. Foot Ankle Surg. 2009, 15:75-81. 10.1016/j.fas.2008.08.003 
2. Best TM, Collins A, Lilly EG, Seaber AV, Goldner R, Murrell GA: Achilles tendon healing: a correlation between functional and mechanical performance in the rat. J Orthop Res. 1993, 11:897-906. 10.1002/jor.1100110617

3. Rotini R, Fini M, Giavaresi G, Marinelli A, Guerra E, Antonioli D, Castagna A, Giardino R: New perspectives in rotator cuff tendon regeneration: review of tissue engineered therapies. Chir Organi Mov. 2008, 91:87-92. 10.1007/s12306-007-0015-2

4. Saladin KS: Connective Tissue. http://www.biologyreference.com/Ce-Co/ConnectiveTissue.html\#ixzz3NyTpGCix.

5. Baergen RN: Manual of Pathology of the Human Placenta, 2nd Ed . Baergen RN (ed): Springer Science+Business, Media, LLC, New York; 2011. 10.1007/978-1-4419-7494-5

6. Bhattacharya N, Stubblefield P: Regenerative Medicine Using Pregnancy-Specific Biological Substances. Bhattacharya N, Stubblefield P (ed): Springer-Verlag, New York; 2011. 10.1007/978-I-84882-718-9

7. Szekeres-Bartho J: Immunological relationship between the mother and the fetus. Int Rev Immunol. 2002, 21:471-495. 10.1080/08830180215017

8. Ueta M, Kweon MN, Sano Y, Sotozono C, Yamada J, Koizumi N, Kiyono H, Kinoshita S: Immunosuppressive properties of human amniotic membrane for mixed lymphocyte reaction. Clin Exp Immunol. 2002, 129:464-470. 10.1046/j.1365-2249.2002.01945.X

9. Veenstra van Nieuwenhoven AL, Heineman MJ, Faas MM: The immunology of successful pregnancy. Hum Reprod Update. 2003, 9:347-357. 10.1093/humupd/dmg026

10. Kubo M, Sonoda Y, Muramatsu R, Usui M: Immunogenicity of human amniotic membrane in experimental xenotransplantation. Invest Ophthalmol Vis Sci. 2001, 42:1539-1546.

11. Hori J, Wang M, Kamiya K, Takahashi H, Sakuragawa N: Immunological characteristics of amniotic epithelium. Cornea. 2006, 25:S53-58. 10.1097/01.ico.0000247214.31757.5c

12. Niknejad H, Peirovi H, Jorjani M, Ahmadiani A, Ghanavi J, Seifalian AM: Properties of the amniotic membrane for potential use in tissue engineering. Eur Cell Mater. 2008, 15:88-99.

13. Davis J: Skin transplantation with a review of 550 cases at John Hopkins Hospital . John Hopkins Hospital Reports. Johns Hopkins Press, Baltimore, MD; 1910. 15:310-396.

14. Stern M: The grafting of preserved amniotic membrane to burned and ulcerated surfaces substituting skin grafts. JAMA. 1913, 60:973-974. 10.1001/jama.1913.04340130021008

15. Toda A, Okabe M, Yoshida T, Nikaido T: The potential of amniotic membrane/amnion-derived cells for regeneration of various tissues. J Pharmacol Sci. 2007, 105:215-228. 10.1254/jphs.CR0070034

16. Trelford JD, Trelford-Sauder M: The Amnion in SurgerThe amnion in surgery, past and present. Am J Obstet Gynecol. 1979, 134:833-845.

17. Di Loreto FP, Mangione A, Palmisano E, Cerda JI, Dominguez MJ, Ponce G, Bernaus M, Gaffuri S, Torresi G, Bianco S: Dried human amniotic membrane as an antiadherent layer for intraperitoneal placing of polypropylene mesh in rats. Surg Endosc. 2013, 27:1435-1440. 10.1007/s00464-012-2604-X

18. Najibpour N, Jahantab MB, Hosseinzadeh M, Roshanravan R, Moslemi S, Rahimikazerooni S, Safarpour A, Ghahramani L, Hosseini SV: The effects of human amniotic membrane on healing of colonic anastomosis in dogs. Ann Colorectal Res. 2013, 1:97-100. 10.5812/acr.16139

19. de Rötth A: Plastic repair of conjunctival defects with fetal membranes . Arch Ophthalmol. 1940, 23:522-555. 10.1001/archopht.1940.00860130586006

20. Kheirkhah A, Casas V, Raju VK, Tseng SC: Sutureless amniotic membrane transplantation for partial limbal stem cell deficiency. Am J Ophthalmol. 2008, 145:787-794. 10.1016/j.ajo.2008.01.009

21. Liu J, Sheha H, Fu Y, Liang L, Tseng SC: Update on amniotic membrane transplantation. Expert Rev Ophthalmol. 2010, 5:645-661. 10.1586/eop.10.63

22. Fairbairn NG, Randolph MA, Redmond RW: The clinical applications of human amnion in plastic surgery. J Plast Reconstr Aesthet Surg. 2014, 67:662-675. 10.1016/j.bjps.2014.01.031

23. Kesting MR, Wolff KD, Hohlweg-Majert B, Steinstraesser L: The role of allogenic amniotic membrane in burn treatment. J Burn Care Res. 2008, 29:907-916. 10.1097/BCR.0b013e31818b9e40

24. Sabella N: Use of Fetal Membranes in Skin Grafting. Med Rec NY. 1913, 83:478-480.

25. Sorsby A, Symons HM: Amniotic membrane grafts in caustic burns of the eye (Burns of the second degree). Br J Ophthalmol. 1946, 30:337-345. 
26. Bujang-Safawi E, Halim AS, Khoo TL, Dorai AA: Dried irradiated human amniotic membrane as a biological dressing for facial burns--a 7-year case series. Burns. 2010, 36:876-882. 10.1016/j.burns.2009.07.001

27. Walker AB, Cooney DR, Allen JE: Use of fresh amnion as a burn dressing. J Pediatr Surg. 1977, 12:391-395. 10.1016/0022-3468(77)90015-X

28. Mohammadi AA, Seyed Jafari SM, Kiasat M, Tavakkolian AR, Imani MT, Ayaz M, Tolide-ie HR: Effect of fresh human amniotic membrane dressing on graft take in patients with chronic burn wounds compared with conventional methods. Burns. 2013, 39:349-353. 10.1016/j.burns.2012.07.010

29. Mohammadi AA, Johari HG, Eskandari S: Effect of amniotic membrane on graft take in extremity burns. Burns. 2013, 39:1137-1141. 10.1016/j.burns.2013.01.017

30. Jin CZ, Park SR, Choi BH, Lee KY, Kang CK, Min BH: Human amniotic membrane as a delivery matrix for articular cartilage repair. Tissue Eng. 2007, 13:693-702. 10.1089/ten.2006.0184

31. Yang JJ, Jang EC, Song KS, Lee JS, Kim MK, Chang SH: The effect of amniotic membrane transplantation on tendon-healing in a rabbit achilles tendon model. Tissue Eng Regen Med. 2010, 7:323-329.

32. Demirkan F, Colakoglu N, Herek O, Erkula G: The use of amniotic membrane in flexor tendon repair: an experimental model. Arch Orthop Trauma Surg. 2002, 122:396-399. 10.1007/s00402-002-0418-3

33. Werber B, Martin E: A prospective study of 20 foot and ankle wounds treated with cryopreserved amniotic membrane and fluid allograft. J Foot Ankle Surg. 2013, 52:615-621. 10.1053/j.jfas.2013.03.024

34. Chao YC, Humphreys S, Penfield W: New method of preventing adhesions - The use of amnioplastin after craniotomy. Br Med J. 1940, 1:517-538.

35. Mohammad J, Shenaq J, Rabinovsky E, Shenaq S: Modulation of peripheral nerve regeneration: a tissue-engineering approach. The role of amnion tube nerve conduit across a 1-centimeter nerve gap. Plast Reconstr Surg. 2000, 105:660-666. 10.1097/00006534200002000-00027

36. Mligiliche N, Endo K, Okamoto K, Fujimoto E, Ide C: Extracellular matrix of human amnion manufactured into tubes as conduits for peripheral nerve regeneration. J Biomed Mater Res. 2002, 63:591-600. 10.1002/jbm.10349

37. Sankar V, Muthusamy R: Role of human amniotic epithelial cell transplantation in spinal cord injury repair research. Neuroscience. 2003, 118:11-17. 10.1016/S0306-4522(02)00929-6

38. Tao H, Fan H: Implantation of amniotic membrane to reduce postlaminectomy epidural adhesions. Eur Spine J. 2009, 18:1202-1212. 10.1007/s00586-009-1013-X

39. Meng H, Li M, You F, Du J, Luo Z: Assessment of processed human amniotic membrane as a protective barrier in rat model of sciatic nerve injury. Neurosci Lett. 2011, 496:48-53. 10.1016/j.neulet.2011.03.090

40. Choi HJ, Kim KB, Kwon YM: Effect of amniotic membrane to reduce postlaminectomy epidural adhesion on a rat model. J Korean Neurosurg Soc. 2011, 49:323-328.

10.3340/jkns.2011.49.6.323

41. Goldschlager T, Ghosh P, Zannettino A, Williamson M, Rosenfeld JV, Itescu S, Jenkin G: A comparison of mesenchymal precursor cells and amnion epithelial cells for enhancing cervical interbody fusion in an ovine model. Neurosurgery. 2011, 68:1025-1034.

10.1227/NEU.0b013e31820d5375

42. Tomita T, Hayashi N, Okabe M, Yoshida T, Hamada H, Endo S, Nikaido T: New dried human amniotic membrane is useful as a substitute for dural repair after skull base surgery. J Neurol Surg B Skull Base. 2012, 73:302-307. 10.1055/s-0032-1321506

43. Gruss JS, Jirsch DW. : Human amniotic membrane: A versatile wound dressing . Can Med Assoc J. 1978, 118:1237-46.

44. Trelford JD, Hanson FW, Anderson DG, Mendel V: Wound healing and the amniotic membrane. J Med. 1975, 6:383-388.

45. Saw VP, Minassian D, Dart JK, Ramsay A, Henderson H, Poniatowski S, Warwick RM, Cabral S, Amniotic Membrane Tissue User Group (AMTUG): Amniotic membrane transplantation for ocular disease: a review of the first 233 cases from the UK user group. Br J Ophthalmol. 2007, 91:1042-1047. 10.1136/bjo.2006.098525

46. Jin $\mathrm{H}, \mathrm{Xu}$ J, Wen $\mathrm{Z}$ : Migratory path of definitive hematopoietic stem/progenitor cells during zebrafish development. Blood. 2007, 109:5208-5214. 10.1182/blood-2007-01-069005 